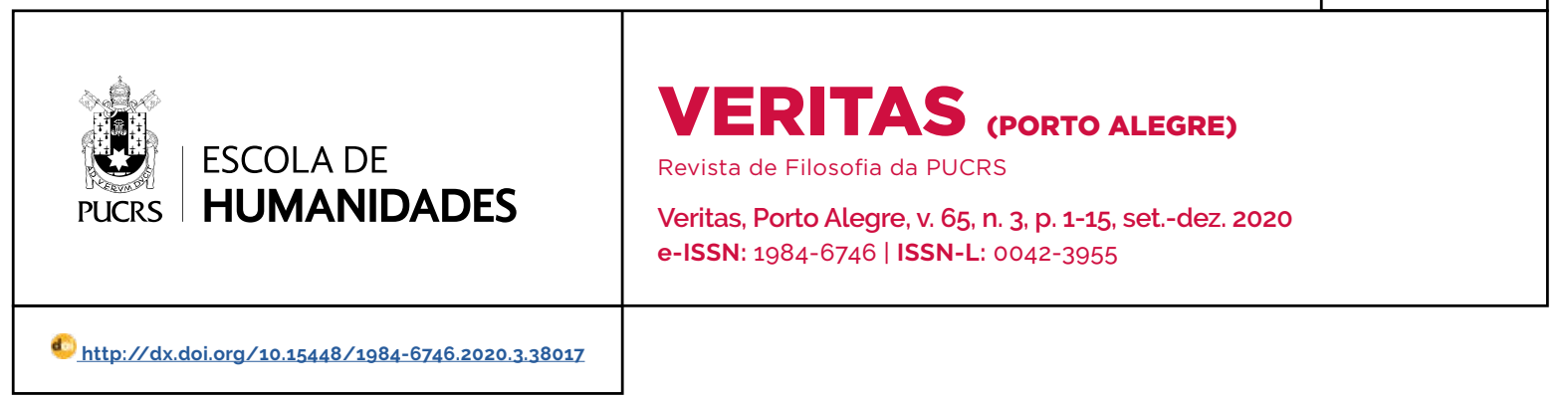

SEÇÃO: VARIA

\title{
A Justiça e o problema da obediência a uma lei injusta - uma análise comparativa das teorias de Rawls e Dworkin
}

\author{
Justice and the problem of obedience to an unjust law - a comparative analysis of \\ Rawl's and Dworkin's theories \\ La justicia y el problema de la obediencia a una lei injusta: un análisis comparativo de \\ las teorias de Rawls y Dworkin
}

\section{Andrei Ferreira de Araújo Lima ${ }^{1}$}

orcid.org/0000-0002-3153-9688 andreidearaujolima@gmail.com

\section{Thadeu Weber ${ }^{1}$ \\ orcid.org/0000-0001-8826-7161 \\ weberth@pucrs.br}

Recebido em: 7/5/2020 Aprovado em: 18/8/2020. Publicado em: 12/01/2021.

\section{(c) (i)}

Artigo está licenciado sob forma de uma licença Creative Commons Atribuição 4.0 Internacional.
Resumo: A possibilidade de se tolerar um desobediente civil é parte integrante, para muitos autores, do próprio conceito de Estado Democrático de Direito. Porém, a fundamentação e os limites da referida desobediência é matéria controversa, mormente quanto à possibilidade de infringir uma lei com fulcro na objeção de consciência. A discussão central, portanto, permeia a incorporação ou não da objeção de consciência como um fundamento válido para a desobediência civil. Percebe-se, a partir deste debate, que questões morais e legais poderão entrar em conflito e os limites da desobediência dependerão da fundamentação e da justificação tanto filosófica quanto jurídica. Frente à vasta e complexa gama de autores que trabalham o tema, optou-se, no presente ensaio, pela análise critica e comparativa das teorias de John Rawls e Ronald Dworkin, que divergem exatamente no ponto acima descrito. O primeiro, alicerçado em sua teoria da justiça como equidade, promove o entendimento procedimental da desobediência civil fundamentada em princípios políticos publicamente aceitos, excluindo questões morais. O segundo, por seu turno, entende que em toda regra há um conteúdo moral, passivel, portanto, de desobediência com fulcro na objeção de consciência. Tendo em vista a referida dicotomia entre princípios morais e princípios políticos, busca-se verificar se a teoria de Rawls impõe um caráter exageradamente restritivo ou se a compreensão de Dworkin traduz comportamentos estatais excessivamente tolerantes. O presente artigo se justifica pela influência decisiva que ambos os autores têm desempenhado no que se refere à fundamentação da desobediência civil, principalmente no debate em relação às doutrinas liberais de justiça.

Palavras-chave: Desobediência civil. Objeção de consciência. Principios políticos. Principios morais.

Abstract: The possibility of tolerating civil disobedience, according to many authors is part of the very concept of the Democratic State of Law. However, the grounds and limits of the referred disobedience are controversial matters, manly as to the possibility to disrespect a law supported by the conscientious objection. The main discussion, therefore, is related to the acceptance or not of the conscientious objection as a valid foundation for civil disobedience. Moral and legal issues may come into conflict and the limits of the disobedience will depend on both philosophical and legal grounds and justification. In view of the vast and complex range of authors working on the theme, we decided in this essay for a critical analysis of the theories of John Rawls and Ronald Dworkin, which diverge exactly at the point described above. The former, based on his theory of justice as fairness, promotes a procedural understanding of civil disobedience, based on publicly accepted political principles, excluding moral issues. The latter, for its part, understands that in every rule there is a moral content, liable, therefore, for disobedience based on the conscientious objection. Once established of the aforementioned dichotomy between moral and political principles, we will seek to demonstrate if Rawls's theory does not end up being excessively restricted or if Dworkin's understanding ends up into excessively tolerant state behaviors. The 
research justifies itself by the decisive influence that both authors have played with regard to the foundation of civil disobedience, mainly in the debate regarding the liberal doctrines of justice.

Keywords: Civil disobedience. Conscientious objection. Political principles. Moral principles.

Resumen: La posibilidad de tolerar la desobediencia civil es una parte integral, para muchos autores, del proprio concepto del Estado democrático de derecho. Sin embargo, los motivos y límites de dicha desobediencia son asuntos controvertidos, en especifico en cuanto a la posibilidad de violar una ley con un enfoque en la objeción de conciencia. La discusión central, por tanto, se encuentra en la posibilidad de incorporar o no la objeción de consciencia como fundamento válido para la desobediencia civil. De este debate se despende claramente que las cuestionen morales y legales pueden entrar en conflicto y los limites de la desobediencia dependerán de una base y una justificación tanto filosóficas como legales. Frente a la amplia y compleja gama de autores que trabajan en el tema, en este ensayo, optamos por un análisis crítico de las teorias de John Rawls y Ronald Dworkin, que divergen exactamente en el punto descrito anteriormente. El primero, basado en su teoría de la justicia como equidad, promueve una comprensión procesal de la desobediencia civil, basada en principios políticos aceptados públicamente, excluyendo cuestiones morales. El segundo, por su parte, entiende que en cada regla hay un contenido moral, responsable, por lo tanto, de la desobediencia con un punto de apoyo en la objeción de conciencia. Ante la dicotomía antes mencionada entre principios morales y políticos, buscamos verificar si la teoría de Rawls impone un carácter excesivamente restrictivo o si la comprensión de Dworkin se traduce en comportamientos estatales excesivamente tolerantes. La justificación de la investigación se establece por la influencia decisiva que ambos autores han juzgado con respecto al fundamento de la desobediencia civil, principalmente en el debate sobre las doctrinas liberales de la justicia.

Palabras clave: Desobediencia civil. Objeción de conciencia. Principios politicos Principios morales.

\section{Introdução}

O tema da obediência de uma lei injusta ou a sua eventual desobediência sempre foi e continua sendo objeto de muitas controvérsias. Questões variadas são colocadas: até que ponto temos o dever de obedecer a leis injustas? Podemos desobedecê-las? Existe uma justificativa plausivel para tal? Até que ponto principios de justiça autorizam desobedecer a leis injustas ou de validade duvidosa?

Partimos do pressuposto geral de que em um Estado Democrático de Direito as leis existem para serem obedecidas. Supõem-se que sejam originárias de instâncias legitimas. Sua eventual desobediência precisa ser devidamente fundamentada e estar circunscrita dos principios de justiça expressos na Constituição.

O propósito do presente estudo é defender a posição de que a desobediência às leis injustas ou de validade duvidosa pode dar-se por razões morais. Acompanha esse intuito a necessidade de explicitar o que se entende propriamente por razões morais. Quais são elas? Envolvem razões de consciência?

Rawls e Dworkin, nesse quesito, divergem. Para o primeiro a definição e a justificação da desobediência de uma lei injusta deve estar de acordo com os principios de justiça que orientam a Constituição de um Estado Democrático de Direito. Dworkin é mais elástico nessa definição, considerando ser possivel a justificação da desobediência por razões de consciência. Identificar onde está exatamente o ponto de discordância é uma preocupação central desse estudo.

O artigo tem como ponto de partida a discussão sobre o dever de obedecer a leis injustas; caracteriza a posição rawlsiana sobre a desobediência civil e apresenta sua justificação. A seguir examina a posição de Dworkin sobre o assunto, destacando diferenças em relação ao primeiro. Por fim, destaca o papel da desobediência dentro de uma Constituição democrática, no sentido de trazer estabilidade para uma sociedade ordenada por uma concepção pública de justiça.

\section{A desobediência civil e sua justificação em Rawls}

\subsection{A obediência a uma lei injusta}

Em que se fundamenta a obediência às leis injustas? Até que ponto temos o dever de obedecê-las? Em Rawls, a resposta a essas questões passa pelos deveres naturais. Um deles é "o dever natural de apoiar instituições justas", entre elas a mais importante, a Constituição. Esse dever, às vezes, requer obediência às leis injustas, considerando o procedimento constitucional da regra da maioria e a Constituição justa. Ocorre que a Constituição é um "procedimento justo", mas imperfeito, ou seja, "não há nenhum processo político factivel que garanta que as leis estabelecidas 
segundo seus parâmetros serão justas" (RAWLS, 1997, p. 392). O critério da maioria é uma "necessidade prática", pois assuntos políticos requerem decisões, que podem ser motivadas pelos mais diferentes interesses. Ora, se temos um dever de apoiar instituições justas, também devemos acatar, por vezes, leis injustas. A regra da maioria é um principio constitucional fundamental, mas que pode errar. Dai se segue que o dever de obedecer a leis injustas decorre do "dever de apoiar uma Constituição justa" (RAWLS, 1997, p. 392). Não se está negando o direito constitucional de legislar da maioria, apenas se está dizendo que disso não resulta que todas as leis elaboradas sejam justas. Estamos falando de "justiça procedimental imperfeita" (RAWLS, 1997, p. 91). O procedimento é admitido como justo, mas o resultado pode ser injusto ou de validade duvidosa.

É oportuno salientar a importância da distinção entre regras e principios, uma vez que a obediência/desobediência se refere às regras e não aos princípios. Os princípios constitucionalmente válidos, em verdade, fundamentam a desobediência, demonstrando a inconstitucionalidade ou a fragilidade da regra. Dworkin, em seu livro Levando os Direitos a Sério, faz essa distinção com um bom exemplo. Trata-se do caso Riggs contra Palmer: um neto mata seu avô para beneficiar-se do testamento no qual fora contemplado (DWORKIN, 2002, p. 37). Considerando o princípio do Direito Costumeiro, segundo o qual "ninguém pode beneficiar-se com seus próprios atos ilicitos", os juizes da Suprema Corte inglesa proferiram a sentença, segundo a qual, o assassino não deveria receber a herança, não aplicando a regra do testamento. O Tribunal argumentou que leis e contratos podem ser limitados, na sua execução, por princípios do Direito Costumeiro.

Além disso, entre principios e regras há uma diferença de natureza lógica: a regra é aplicável "à maneira tudo-ou-nada" (DWORKIN, 2002, p. 39). Uma regra não pode contradizer outra. Isso não ocorre com os princípios. Esses não têm consequências jurídicas imediatas. A natureza da orientação que oferecem é, pois, diferente. Em favor dos princípios, também conta uma diferença em relação ao grau de importância. Quando houver conflitos, é preciso examinar a força dos argumentos que podem ser aduzidos em favor de cada um. Ambos podem continuar valendo. O que muda é a sua aplicação. No caso de conflitos de regras, uma não pode ser válida. Ou quando não há regras ou quando são controversas, os tribunais recorrem aos princípios para justificar a adoção e a aplicação de novas regras. Regras fundamentam-se em princípios, e esses se constituem de valores passiveis de justificação pública. ${ }^{2}$

É importante frisar que quando falamos de leis estamos nos referindo ao processo legislativo e nele, ao critério da maioria. É o que Rawls refere como um caso de justiça procedimental imperfeita: mesmo que o procedimento seja justo (de acordo com o sistema público de regras) o resultado pode ser injusto. Leis injustas podem ser promulgadas.

Ora, reconhecidos os princípios de justiça e o critério da maioria, como recurso procedimental, às vezes temos o dever de obedecer às leis injustas, considerando o dever de apoiar uma Constituição justa. No entanto, pela mesma razão temos que admitir a possibilidade de desobedecer às leis injustas, ou seja, uma teoria constitucional da desobediência civil se justifica. É em nome de princípios que leis injustas ou de validade duvidosa podem ser desobedecidas.

\subsection{0 que é desobediência civil? (Rawls)}

Nunca é demais insistir que Rawls defende uma concepção política de justiça. O que tem em vista é a "estrutura básica da sociedade", isto é, suas principais instituições políticas e sociais. Se reconhece uma concepção pública de justiça e admite-se que as principais instituições a efetivem. A desobediência civil (o desobediente civil) reconhece a legitimidade e a justiça da Constituição, mas se posiciona de forma contrária a certas leis injustas. É importante lembrar

\footnotetext{
2 Sobre a relação entre regras, principios e valores, ver C. Perelman, Ética e Direito. Parte I. Ainda, Alexy, corrobora a tese quando em sua obra afirma: "não importa a forma como sejam fundamentados, não é possivel que dois juizos concretos de dever-ser contraditórios entre si sejam válidos" (ALEXY, 2015, p. 92).
} 
que a desobediência pode ser manifestada não necessariamente contra uma determinada lei tida como injusta. É o que Rawls chama de "desobediência civil indireta". Pode-se desobedecer a uma lei de trânsito ou desrespeitar o direito de propriedade com o propósito de chamar a atenção para seus argumentos contra uma lei injusta (RAWLS, 1997, p. 404).

É preciso lembrar que existem várias maneiras de exercer o direito de resistência, a desobediência civil é apenas uma delas. É uma "forma particular de resistência" (VIANA, 1996, p. 54). A objeção de consciência e a resistência armada estão entre as outras formas de resistência. $O$ problema da desobediência civil, tal como Rawls o entende, só se coloca "no âmbito de um estado democrático", no qual "os cidadãos reconhecem e aceitam a legitimidade da Constituição" (RAWLS, 1997, p. 403). ${ }^{3}$ É em nome dela e de seus principios justos que a desobediência às leis injustas é exercida. O dever de se opor à injustiça e de defender direitos e liberdades fundamentais, por vezes, retira a obrigatoriedade de acatar leis injustas estabelecidas pela maioria do poder legislativo. Isso indica a importância, mas também os limites da regra da maioria. ${ }^{4}$

Em Uma Teoria da Justiça, Rawls define a desobediência civil como um "ato público, não violento, consciente e não obstante um ato político, contrário à lei, geralmente praticado com o objetivo de provocar uma mudança da lei e nas políticas do governo" (RAWLS, 1997, p. 404).

Dizer que é um ato público significa que, além de se dirigir a princípios públicos, representa um "apelo público"; é feito em público e não é secreto (RAWLS,1997, p. 405). A desobediência visa "denunciar a injustiça contida na lei", tendo em vista a sua reformulação (VIANA, 1996, p. 57). Por isso, não é feita às escondidas.

Não ser um ato violento, é de muito difícil caracterização. De que tipo de violência estamos falando, a violência física, a psicológica? Bloquear uma avenida com o intuito de protestar contra a injustiça de uma lei não poderia ser entendido como um tipo de violência contra o direito de ir e vir? De qualquer sorte, para Rawls, a desobediência não se dirige contra as pessoas; não faz uso da força por princípio (RAWLS, 1997, p. 405). A interferência nas liberdades civis das pessoas desqualifica a desobediência civil como tal.

A desobediência civil não é violenta por se dar dentro dos "limites da fidelidade à lei". Essa fidelidade é "expressa pela natureza pública" e "pela disposição de aceitar as consequências jurídicas da própria conduta" (RAWLS, 1997, p. 406). Trata-se de um apelo ao "senso de justiça do público".

Ser um ato político significa que "se orienta e justifica por principios políticos" (RAWLS, 1997, p. 405). Trata-se de principios acordados na posição original e que orientam a Constituição. São aqueles principios resultantes de um procedimento justo, e é justo porque equitativo. O desobediente não pode, todavia, apelar para principios religiosos ou de moral pessoal. É preciso insistir que Rawls defende uma "teoria constitucional da desobediência civil" (1997, p. 403). Trata-se, pois, de um ato contrário à lei, mas não inconstitucional. O intuito é, pois, "provocar uma mudança na lei e nas políticas do governo" (RAWLS, 1997, p. 404). A desobediência é, pois, o direito de exercer uma resistência às leis injustas ou de validade duvidosa, motivada por principios justos.

Por essa caracterização pode se observar que a desobediência civil se distingue claramente da objeção de consciência, uma vez que essa se caracteriza por ser uma recusa a uma ordem estabelecida por "razões de consciência".

Diferentemente da desobediência civil, a objeção de consciência não é um ato público, nem via de regra toma como base princípios políticos, mas pode orientar-se por principios religiosos ou razões de consciência. Também não apela ao senso de justiça da maioria (RAWLS, 1997, p. 408). A recusa de um pacifista a servir às forças armadas é um exemplo dado pelo próprio Rawls. O mesmo ocorre quando alguém se recusa a pagar um imposto

\footnotetext{
3 Juan I. U. Eceizabarrena, em seu livro La Desobediencia Civil en el Estado Constitucional Democrático, examina exaustivamente o papel da desobediência civil no Estado Democrático de Direito.

4 Sobre a importância e os limites da regra da maioria, ver: RAWLS, 1997, p. 395
} 
por julgar que está sendo utilizado para a prática de graves injustiças contra as pessoas. A questão é saber se é possivel justificar uma desobediência a uma lei injusta por razões de consciência.

\subsection{A justificação da desobediência civil}

A justificação da desobediência civil é certamente o ponto de maior divergência entre Rawls e Dworkin. Coerente com sua concepção de justiça, e diferentemente de Dworkin, Rawls não admite ser a desobediência civil justificada por razões de consciência. Para Dworkin, essa possibilidade existe.

Se, para Rawls, os princípios de justiça se caracterizam por serem públicos e por orientarem as principais instituições políticas e não dependerem de doutrinas éticas abrangentes, é motivado por eles e em nome deles que o desobediente deve agir. Isso significa que: 1) qualquer violação de direitos fundamentais previstos no primeiro princípio de justiça, bem como qualquer infração ao princípio da igualdade equitativa de oportunidades justifica a desobediência civil. Negar o acesso a cargos públicos a determinadas minorias; não reconhecer o direito de votar; negar oportunidades iguais a todos, caracterizam graves violações de direitos fundamentais. Logo, passiveis de desobediência; 2) a desobediência civil sempre deveria ser o último recurso. Os meios legais para a mudança da lei devem ter sido esgotados e não obtiveram êxito; "as tentativas de provocar a revogação das leis injustas foram ignoradas" (RAWLS, 1997, p. 413); as demonstrações e protestos se mostraram inúteis. ${ }^{5} \mathrm{~A}$ alternativa que resta é a desobediência. A liberdade de expressão, no entanto, sempre deve ser garantida, ainda que não se faça uso da desobediência.

Pode-se observar que se trata de uma concepção bem restrita de desobediência civil e de sua justificação. Somente razões políticas ou o apelo a valores políticos podem justificar a desobediência à lei injusta. Rawls se reporta explicitamente a Dworkin no que se refere à concepção muito abrangente de desobediência civil, uma vez que esse admite razões de consciência para a sua justificação. Além do mais, Rawls refere-se apenas às leis injustas e politicas do governo e não a outras formas de injustiças, que poderiam ser objeto de desobediência. Eceizabarrena situa a concepção rawlsiana de desobediência civil entre o que ele chama de "definição ortodoxa", exatamente por ser muito restritiva (1999, p. 38). A posição de Rawls, no entanto, é coerente com sua concepção política de justiça. Se doutrinas éticas abrangentes não podem fundamentar princípios políticos de justiça é claro que também não podem ser usados como justificação da desobediência civil.

\section{A desobediência civil em Dworkin}

Em Levando os Direitos a Sério, referindo-se aos EUA, Dworkin parte de uma tese fundamental: "os cidadãos têm alguns direitos morais contra seu governo" (DWORKIN, 2002, p. 283). A questão é saber o que são exatamente direitos morais e quais são eles. Envolvem razões de consciência? Razões morais podem ser apresentadas como justificativa para desobedecer às leis injustas ou de validade duvidosa?

Ocorre que Dworkin, diferentemente de Rawls, defende uma mútua imbricação entre questões jurídicas e questões morais. Isso é importante para os debates sobre desobediência civil e sua justificação. "A Constituição funde questões jurídicas e morais, fazendo com que a validade de uma lei dependa da resposta a problemas morais complexos, como o problema de saber se uma determinada lei respeita a igualdade inerente a todos os homens" (DWORKIN, 2002, p. 285). Problemas morais, portanto, são fundamentais para a discussão da validade de uma lei. O princípio da igualdade é um deles. Objeções morais podem tornar a validade de uma lei, no mínimo, duvidosa, quando não claramente injusta. Dworkin, diferentemente de Rawls, não é contratualista. O conteúdo de seus principios é mais amplo do que o de Rawls. Podem originar-se, inclusive, do direito costumeiro, envolvendo questões éticas e morais.

5 Ver, também: VIANA, 1996, p. 56 
Referindo-se especificamente à desobediência civil, Dworkin pergunta: "de que forma o governo deveria proceder com aqueles que desobedecem, por razões de consciência, às leis referentes ao recrutamento militar?" (DWORKIN, 2002, p. 315). Verifica-se que nesse questionamento razões de consciência são admitidas para justificar a desobediência civil. No entanto, por esse caso (recrutamento), não se pode concluir que qualquer lei duvidosa possa ser desobedecida por razões de consciência. A referência explícita é ao caso do recrutamento militar. Também para Rawls os casos de recrutamento são objeto de objeção de consciência e não de desobediência civil. Todavia, mais adiante se verá que Dworkin admite razões de consciência para estabelecer a dubiedade de qualquer lei e, portanto, justificar a desobediência civil.

\subsection{A desobediência a uma lei de validade duvidosa ou ambígua}

Para Dworkin, o problema da desobediência civil não é o da validade ou não da lei. Se a lei for válida cabe obediência; se for inválida, por ser inconstitucional, cabe desobediência. O que está em jogo na desobediência civil é a validade duvidosa ou ambigua da lei. E o que torna a validade duvidosa? A resposta é taxativa: razões morais. Afirma o autor: "pelo menos nos Estados Unidos, quase todas as leis a que um número significativo de pessoas seria tentado a desobedecer por razões morais são também duvidosas, - quando não claramente inválidas por razões constitucionais. A Constituição torna a nossa moral política convencional relevante para a questão da validade" (DWORKIN, 2002, p. 318). O peso dado às razões morais é evidente. São capazes de estabelecer a dubiedade das leis, inclusive questionar a sua constitucionalidade. Não se trata, obviamente, de qualquer número de pessoas, mas de um "número significativo" delas que se manifestam sobre a validade de uma lei.

Com o intuito de esclarecer a importância das questões morais para as próprias questões juridicas, o autor em pauta dá como exemplo as objeções apresentadas nos protestos contra o recrutamento militar dos anos 1960, por ocasião da guerra do Vietnã. Os protestos se baseavam em objeções morais, que, aliás, forneceram a base para argumentos constitucionais. A título de exemplo podemos citar a seguinte objeção moral: "se um exército deve ser recrutado para lutar nessa guerra, é imoral fazê-lo através de um recrutamento que adie a apresentação ou isente da prestação os estudantes universitários, discriminando assim os menos favorecidos economicamente" (DWORKIN, 2002, p. 319). Essa objeção serviu de base para o seguinte argumento constitucional: "de qualquer modo, a discriminação em favor dos estudantes universitários negava aos pobres a igual proteção da lei, que é assegurada pela Constituição" (DWORKIN, 2002, p. 320). É fácil concluir, portanto, que uma lei que favorece determinado grupo de pessoas (os estudantes universitários, por exemplo) é de validade duvidosa. Logo, passivel de ser desobedecida por razões morais. Mas não somente por essas, também por razões jurídicas, por ser inconstitucional. Trata-se de uma lei discriminatória.

Se o que está em jogo é a validade duvidosa ou ambigua de uma lei, e para tal razões de consciência são suficientes, uma questão imediatamente se impõe: "o que deve fazer um cidadão quando a lei não for clara e ele pensar que ela permite algo que, na opinião dos outros, não é permitido?" (DWORKIN, 2002, p. 321). Dworkin apresenta três alternativas: $1^{\mathrm{a}}$ ) se a lei é duvidosa o cidadão "deve imaginar o pior e agir pressupondo que a lei não permite" (2002, p. 322). Mesmo que considere a lei injusta, deve obedecê-la; $2^{\mathrm{a}}$ ) se a lei é duvidosa o indivíduo pode seguir seu "próprio discernimento somente até o ponto em que uma instituição autorizada, como um tribunal, decida o contrário" (2002, p. 322). Em havendo uma "decisão institucional" deve ser obedecida ainda que discorde dela; $3^{a}$ ) se a lei é duvidosa, o indivíduo pode seguir seu próprio discernimento, "mesmo depois de uma decisão em contrário" (2002, p. 323). Acrescente-se a essa terceira alternativa que o cidadão deve levar em consideração a justificação apresentada pelo tribunal competente. O fato é que as decisões dos tribunais podem modificar a interpretação de uma lei e isso precisa ser levado 
em conta para uma eventual desobediência. É preciso avaliar se na nova interpretação da lei persistem as razões para desobedecê-la. Pois se assim for, o cidadão pode achar que, apesar de uma decisão em contrário da Corte, o direito está do seu lado. Dworkin insiste no fato de que as decisões da Suprema Corte podem sempre ser modificadas. Por isso, "não se pode pressupor que a Constituição é sempre o que a Suprema Corte afirma que ela é" (DWORKIN, 2002, p. 323).

$\mathrm{O}$ autor rejeita as duas primeiras alternativas e adota a terceira.

Digno de nota é o arrazoado apresentado para refutar a segunda alternativa. Essa rejeição se deve ao fato de que essa alternativa ignora que qualquer tribunal, e inclusive a Suprema Corte, pode mudar de posição. Dworkin dá o exemplo da lei que exigia a saudação à bandeira por parte dos estudantes: em 1940 a decisão da Suprema Corte era pela constitucionalidade da referida lei do Estado da West Virginia. Em 1943, mudou de posição e decidiu pela inconstitucionalidade da referida lei. A questão é: e os cidadãos que se recusaram a saudar a bandeira em 1941 e 1942, "por razões de consciência", qual seria seu dever? Alguém poderia argumentar no sentido de que a lei deve ser obedecida em sua vigência, enquanto se tomam medidas institucionais e legais junto ao poder legislativo para a sua modificação ou mesmo extinção. Para Dworkin, essa seria uma "recomendação plausivel se não envolvesse consciência" (2002, p. 327). Acatar uma lei ambígua quando a consciência o proibe, representa uma violação da consciência.

Mais uma vez fica claro que razões de consciência são suficientes para justificar a desobediência de uma lei de validade duvidosa. Por admitir a possibilidade da desobediência mesmo depois de uma decisão da Suprema Corte, a terceira alternativa é a adotada. O desobediente poderá continuar julgando que o direito está do seu lado, mesmo depois de uma reinterpretação e explicitação de uma lei ambígua, por quem de direito. A dubiedade de uma lei precisa assegurar o livre discernimento do cidadão e, portanto, a possibilidade da desobediência. Nesse caso, Rawls é muito feliz com a defesa de uma "teo- ria constitucional da desobediência civil". O ato de desobediência é contrário à lei, mas não é inconstitucional. Para Dworkin, "quando uma lei for incerta, no sentido de permitir uma defesa plausivel de dois pontos de vista contrários, um cidadão que siga seu próprio discernimento não está deixando de se comportar de maneira equitativa" (2002, p. 330). O governo deve, pois, protegê-lo. Os dois autores, portanto, admitem e defendem a constitucionalidade da desobediência a uma lei injusta ou de validade duvidosa, porém, com fundamentações distintas.

Saliente-se que na terceira alternativa a decisão de um Tribunal competente assume um papel fundamental: o desobediente deve levar em consideração aquela decisão com a devida ponderação e razoabilidade. Uma nova argumentação e justificação pode ser introduzida na tentativa de sanar a ambiguidade. Por outro lado, e apesar disso, um direito fundamental pode estar sendo afetado e a desobediência deveria ser admitida. Erros sempre são possíveis, mesmo em uma decisão da Suprema Corte. Quando isso ocorre o cidadão deve ter o direito de não a aceitar. Escreve Dworkin:

\begin{abstract}
se a matéria em discussão afetar direitos individuais ou politicos fundamentais, e se for possivel argumentar que a Suprema Corte cometeu um erro, um indivíduo não extrapolará os limites de seus direitos sociais ao se recusar a aceitar essa decisão como definitiva (DWORKIN, 2002, p. 328).
\end{abstract}

Mais polêmica, no entanto, é a justificação da desobediência civil por razões de consciência, admitida por Dworkin e recusada por Rawls. Esse considera a desobediência civil como qualquer desobediência à lei por razões de consciência, ampla demais (RAWLS, 1997, p. 408). Quando os princípios da justiça são claros e entendidos como conteúdo de uma concepção política, razões alheias a esse conteúdo podem gerar ainda mais ambiguidades.

\subsection{Objeção de consciência - Toda lei contém um conteúdo moral}

Como já apontado, a diferença central entre a teoria de Rawls e a de Dworkin, em relação 
à desobediência civil, está na abrangência das razões que possam ser arguidas em favor do dissidente. Ambos concordam que os principios constitucionais serão os principais motivadores da desobediência. Porém, enquanto Rawls mantém sua teoria vinculada ao ideal de Estado quase-justo, quer dizer, a própria desobediência civil deve seguir principios constitucionais (princípios de justiça) previamente estabelecidos e publicamente aceitos, Dworkin, aproximando-se do sentido clássico da desobediência, ${ }^{6}$ entende que não somente princípios constitucionais, mas também razões morais particulares podem ensejar o descumprimento da lei. Trata-se, portanto, da inclusão da objeção de consciência como fundamento da desobediência civil.

Não há, para Dworkin, uma diferença relevante na desobediência civil fundamentada em um principio constitucional ou em uma objeção de consciência. O elevado grau de moralidade atribuido pelo autor às leis desempenha significativo papel nos desdobramentos da análise dos atos dos dissidentes. A validade das leis perpassa pela moralidade dos mandamentos nelas inseridos, logo, elas poderão ser descumpridas com base em mandamentos morais, mesmo que de particulares, ou de morais abrangentes.

Existindo, portanto, dúvidas quanto à moralidade da lei, há, igualmente, dúvida quanto à constitucionalidade da lei, pois segundo o autor "qualquer lei que pareça comprometer essa moral levanta questões constitucionais, e, se esse comprometimento for grave, as dúvidas constitucionais também serão graves" (DWORKIN, 2002, p. 318.).

No caso do recrutamento, diversas foram as questões arguidas pelos dissidentes quanto à validade moral da lei. Duas, dentre aquelas apresentadas por Dworkin, chamam mais a atenção. A primeira delas, como já mencionado, diz respeito a um possivel caráter discriminatório da lei, uma vez que ela privilegiava o recrutamento de cidadãos que não estavam cursando o ensino superior, logo, aqueles menos favorecidos economicamente. A segunda questão moral ligada ao recrutamento dizia respeito à dispensa daqueles que são contrários a quaisquer guerras por motivos religiosos, mas não daqueles que são contrários a determinadas guerras por questões morais seculares (DWORKIN, 2002, p. 319).

A esse respeito, cabe abordar a critica promovida por Dworkin em relação a uma aparente graduação das razões de consciência, ou seja, por que algumas razões morais parecem ter prevalência em relação a outras? No exemplo elencando pelo autor, no qual a objeção de consciência à guerra seria o suficiente para desonerar o cidadão da obrigatoriedade de recrutamento, o Estado Norte-Americano dispensou aqueles que alegavam objeção de consciência religiosa à guerra, mas não aqueles que justificam sua objeção de consciência em razão de outros fundamentos morais, como, por exemplo, o fato de ser um pacifista.

Para Dworkin, aceitar a objeção de consciência apenas com fundamento na moral religiosa significa dizer que existem argumentos morais com maior validade do que outros. Significa dizer que o segundo grupo, aquele com objeções morais seculares, "é menos digno do respeito do país que o primeiro" (DWORKIN, 2002, p. 319).?

Cabe apontar que Dworkin apresenta sua defesa ao respeito às mais variadas morais abrangentes, em outros escritos, com destaque para a obra Domínio da Vida, na qual debate temas da mais alta complexidade moral, expondo reiteradamente a necessidade de aceitação e respeito à autodeterminação e aos interesses individuais, sejam eles fundamentados em razões morais seculares ou religiosas. $O$ autor fala em interesses fundamentais, religiosos ou não, que são as convicções pessoais atreladas às decisões

\footnotetext{
6 O próprio Rawls diz se afastar do conceito clássico. Segundo o autor: "embora eu tenha diferenciado a desobediência civil da objeção de consciência, ainda preciso explicar a segunda ideia. É o que farei agora. É preciso reconhecer, porém, que separar essas duas ideias significa oferecer uma definição mais restrita de desobediência civil do que a tradicional, pois é comum considerar a desobediência civil no sentido mais amplo como qualquer desobediência à lei por motivos de consciência, pelo menos quando não é dissimulada e não envolve o uso da força. O texto de Thoreau é característico, se não definidor, do significado tradicional" (2008, p. 458).

7 Defensores da tese que apenas argumentos religiosos podem valer para o não recrutamento entendem que se qualquer discurso moral for o suficiente para dispensar o recrutamento, o argumento será abrangente demais. De certa forma, vinculando somente à religião, seria mais fácil de se realizar um controle.
} 
de cada cidadão (DWORKIN, 2009, p. 275). Tais interesses, não sendo flagrantemente contrários a principios constitucionais, não causando danos a terceiros e inseridos em parâmetro de justiça e equidade, devem ser respeitados.

A objeção de consciência, portanto, pode servir de argumento para a desobediência civil. Segundo o autor, o dissidente, mesmo contrariando uma decisão da Suprema Corte, deverá testar publicamente seus argumentos, como se fosse um exercício do contraditório em relação à lei. A aceitação social, ou não, dos argumentos dos dissidentes poderá desempenhar papel fundamental em um possivel julgamento e em uma punição em razão de seus atos.

\subsection{A aceitação pública e o contraditório}

Ponto interessante e de convergência nas obras dos autores é a necessidade de os dissidentes verificarem publicamente a validação de suas contrariedades. Rawls entende que o procedimento assegura a aceitação pública da desobediência, uma vez que está de acordo com princípios previamente ajustados e transportados para a constituição. Dworkin, mesmo que incorporando a objeção de consciência como possivel fundamento para a desobediência civil, defende que o dissidente deve ter boas razões para desrespeitar uma regra e deve verificar publicamente seus argumentos. Segundo o autor, uma lei deve ser testada e desenvolvida

\begin{abstract}
através de experimentação praticada pelos cidadãos e através do procedimento do contraditório. Nosso sistema persegue esses objetivos convidando os cidadãos para decidirem sobre a força e a fragilidade dos argumentos juridicos, por si mesmos, ou através de seus representantes nos tribunais, e para agirem com base nesses juizos (DWORKIN, 2002, p. 332).
\end{abstract}

Nesse ponto, o autor reforça o entendimento de que a terceira opção, daquelas elencadas como possiveis ações para desobediência, é a mais adequada. Teria, então, todo cidadão o direito de desobedecer a uma lei? Mesmo após a decisão da Corte Superior? Dworkin entende que sim, porém, deve saber o dissidente que sobre ele recai o ônus da justificação e caso não seja bem-sucedido em sua argumentação, deverá arcar com as consequências negativas de seu ato (2002, p. 323). De qualquer sorte, entende o autor que aguardar um longo periodo para que um tribunal ou para que a Corte Superior decida quanto à legalidade da lei, poderá demandar extenso lapso temporal, durante o qual o cidadão terá que suportar constantes violações de consciência, causando-lhe injusto, grave e desnecessário sofrimento.

Uma vez ciente dos riscos da desobediência e consciente de que sobre ele recai a necessidade de argumentação, o cidadão, em dúvida, pode desrespeitar a lei inclusive como uma forma de expor suas razões, contraditando o entendimento da validade da lei e testando a opinião popular frente ao seu comportamento dissidente (DWORKIN, 2002, 332). Existindo um número significativo de cidadãos que não percebem no ato dos dissidentes qualquer atitude imoral, ou injusta ou, até mesmo, não equânime, o autor defende que "[...] não pode ser injusto deixar de puni-lo se ele estiver agindo, dadas suas opiniões, como achamos que deve agir" (DWORKIN, 2002, 321). Ou seja, se nossas convicções morais coincidem com as convicções que levaram determinada pessoa a agir contrariamente à lei, provavelmente ela esteja certa e a lei seja inconstitucional.

Dworkin, cautelosamente, reforça: "o sucesso dessa estratégia depende de sabermos se existe, na comunidade, consenso suficiente sobre o que se considera como um bom ou mau argumento" (DWORKIN, 2002, p. 332). Se a sociedade tolera a desobediência é porque ela está de acordo com a moral vigente, ao menos da maioria, e, portanto, não há razões para punições. Na pior das hipóteses, o Estado deve aguardar maiores discussões e desdobramentos acerca da desobediência em questão, evitando que os dissidentes sejam julgados de modo imprudente, ocasionando punições desproporcionais.

De modo a evitar julgamentos precipitados, Dworkin percebe grande valor no exercício da tolerância para a resolução de problemas vinculados à desobediência civil. Pode-se dizer que os conceitos de objeção de consciência, exercício do 
contraditório e a prática da tolerância estão mutuamente imbricados. A validade de um dependerá da validade dos outros. Nesse sentido, Dworkin fala em equilibrio antes de julgar e punir cidadão, pois regras inflexiveis em nada ajudarão (2002, p. 332).

Tal linha de raciocínio parece, prima facie, ser abrangente demais, a ponto de o Estado, principalmente no que toca à instituição legislativa e à judiciária, ser ignorado. Parece conceder ao cidadão irrestrito direito de não obedecer à lei, uma vez que bastariam suas razões morais. Parece exigir do Estado uma indevida demora, ocasionando grande instabilidade social.

Evidente que questionamentos quanto à segurança jurídica, à ordem social e ao respeito às instituições estatais surgem a partir desse posicionamento. Não deveriam os dissidentes serem punidos de imediato e de modo exemplar antes que a corrupção se dissemine? (DWORKIN, 2002, p. 315) Muitos autores entendem que sim, no sentido de que lei e moral são institutos distintos e que a estabilidade social depende de punição rápida e exemplar aos dissidentes. Dworkin contesta essa acepção, afirmando que da lógica que pune implacavelmente os dissidentes, não se segue que a sociedade irá desmoronar se tolerar alguma desobediência (2002, p. 316).

Porém, necessário se faz o estabelecimento de critérios ou de princípios a limitarem a tolerância frente ao ato contrário à lei. O autor deixa claro que "alguns principios podem ser estabelecidos" (DWORKIN, 2002, p. 332). Tais principios perpassam por valores morais que sustentam as regras, como por exemplo aqueles insculpidos nas leis de direitos civis, constitucionalmente assegurados e, portanto, dignos de respeito e de obediência. Regras que estabelecem que os indivíduos, exemplificadamente, têm o direito moral de não sofrerem uma lesão, são regras com um poderoso argumento contra a tolerância às violações que promovem esses danos (DWORKIN, 2002, p. 333).

Quando a desobediência a uma lei acaba por violar a moral de um terceiro, não haveria razões para o Estado tolerá-la. Retomando o exemplo dos dissidentes do recrutamento, o autor explica que se esses homens tivessem incentivado a violência ou, de algum modo, infringido os direitos de outros, estaria configurada uma forte justificativa para a instauração de um processo. Contudo, na ausência de tais ações, o equilibrio da equidade e da utilidade parece-me estar do outro lado, razão pela qual considero errada a decisão de processar Coffin, Spock, Raskin, Goodman e Ferber (DWORKIN, 2002, p. 335).

Ainda, Dworkin defende que a Suprema Corte mesmo entendendo a validade da lei de recrutamento, não deveria condenar os dissidentes, pois existia uma dúvida no momento da recusa. O autor compara esse entendimento à "condenação com base em uma lei penal cujos termos não são vagos, mas cuja validade constitucional é duvidosa" (DWORKIN, 2002, p. 339). Uma lei com essa natureza fere a cláusula de processo regular, pois primeiramente deixa o cidadão em situação de total desvantagem, e, em segundo lugar, a condenação a partir de uma lei duvidosa, sobre a qual o promotor ou os tribunais acabam por legislar, fere o princípio da separação dos poderes (DWORKIN, 2002, p. 340). Como poderiam, então, dissidentes serem julgados culpados quando ainda há dúvida em relação à constitucionalidade de uma lei? Se o ato de desobediência não coloca em risco qualquer direito de terceiros, qual a grave urgência em julgá-lo? A tolerância desempenharia papel fundamental nesse caso, fornecendo o tempo necessário para a maturação do tema, bem como a promulgação de novas leis, eliminando as dubiedades morais, pelo órgão competente para tanto, não por tribunais ou pela Suprema Corte.

Por fim, cabe salientar que, para Dworkin, regras contêm mandamentos morais, que por sua vez, estão atrelados aos principios constitucionais. Se uma regra viola a consciência de um determinado individuo ou de um grupo de pessoas, há, portanto, grande chance de essa regra igualmente violar a constituição, sendo plausivel a desobediência a uma norma jurídica com fulcro na objeção de consciência. É a reinterpretação constante da ciência juridica frente aos novos desafios sociais, que permite tais conclusões. Dessarte, Dworkin encerra o capítulo afirmando que interpretações inflexiveis ou draconianas não são meios de resolução para a desobediência 
civil, pois "a regra jurídica é mais complexa e inteligente do que isso e é importante que ela sobreviva" (2002, p. 341).

\section{0 papel da desobediência civil - Divergências e convergências entre Rawls e Dworkin}

É importante frisar que estamos falando da desobediência civil dentro de uma Constituição Democrática, cujo núcleo central é "reconhecimento e a garantia dos direitos fundamentais, a vigência do princípio democrático e a submissão do poder público ao Direito" (ECEIZABARRENA, 1999, p. 63). É, pois, ela que orienta a conduta política dos cidadãos, inclusive a desobediência de leis injustas ou de validade ambígua, emanadas do poder legislativo. Em outras palavras, são civis aquelas desobediências realizadas em nome daquela Constituição e seus princípios.

Embora entendida em diferentes graus de abrangência em Rawls e Dworkin, portanto com diferentes formas de justificação, a desobediência civil exerce um papel importante em uma democracia. Traz estabilidade para uma sociedade ordenada por uma concepção pública de justiça. Se aceitarmos que a nossa sociedade é "um sistema de cooperação entre iguais", os cidadãos prejudicados com graves injustiças precisam ter a possibilidade da desobediência. Isso não enfraquece o Estado Democrático de Direito, antes o fortalece, impõe mais rigor ao poder legislativo e transparência nas decisões. Rawls considera a desobediência civil como um dos "recursos estabilizadores de um sistema constitucional" (RAWLS, 1997, p. 434). Para ele, ela visa um apelo ao "senso de justiça da maioria" (1997, p. 424). Por isso que é pública e pautada em princípios políticos. Supõe-se, então, que o desobediente tenha uma opinião "sincera e ponderada" sobre a violação das condições da cooperação social. A desobediência civil, segundo o autor, "ajuda a manter e a reforçar as instituições justas"; "serve para manter e prevenir desvios da rota da justiça e para corrigi-los quando acontecem" (RAWLS, 1997, p. 425).

Considerando, portanto, a sociedade como um sistema equitativo de cooperação, orientada por uma concepção pública e política de justiça e admitindo o critério da maioria como recurso procedimental constitucional, mas que pode errar instituindo leis ambiguas ou injustas, a prática da desobediência é admissivel. Nesse caso, a democracia deve incluir a tolerância para com os desobedientes. Para Dworkin, "tolerar o dissenso" é uma maneira de permitir que o debate continue até que se atinja maior clareza sobre a ambiguidade (conteúdo) de uma lei (DWORKIN, 2002, p. 337).

No entanto, é preciso salientar que a desobediência civil, em Rawls, como já foi lembrado por ocasião da sua justificação, é o "último recurso para manter a estabilidade de uma Constituição justa" (1997, p. 426). Ele pressupõe, pois, que medidas legais já foram esgotadas para a mudança da lei ou a explicitação de seu conteúdo ambíguo. Ao passo que Dworkin, ao eleger a terceira hipótese daquelas por ele entendidas com um comportamento aceitável do dissidente (2002, p. 337), entende que a desobediência à lei é atitude plausivel desde o primeiro momento em que o dissidente se sente ofendido, de modo que não há a necessidade de aguardar o esgotamento de todas as medidas legais.

O que chama atenção em Rawls, ao referir-se ao "papel da desobediência civil" é o fato de considerá-la "um modo moralmente correto de manter um regime constitucional" (RAWLS, 1997, p. 426, grifo nosso). O que se deve entender pelo "moralmente correto"? Razões de consciência, certamente, não estão incluídas. Sua teoria constitucional da desobediência civil está diretamente ligada à sua concepção política de justiça, que é parte da moral, mas independente de doutrinas éticas abrangentes. Isso significa dizer que uma teoria constitucional da desobediência civil se fundamenta em uma concepção política e pública de justiça. Apoia-se nos principios de justiça frutos do "equilibrio reflexivo" e de um "consenso sobreposto".

Ao justificar a desobediência civil, diz o autor que "em momento algum se fez referência a principios que não fossem políticos; concepções religiosas e pacifistas não são essenciais" (RAWLS, 1997, p. 426). Rawls, no entanto, parece, porvezes, 
não distinguir claramente razões morais de razões éticas, como aliás, refere Forst em Contextos da Justiça (FORST, 2010, p. 57). ${ }^{8}$ De qualquer sorte, o "moralmente correto" não se refere a valores éticos, mas, tão somente, a valores políticos. Isso fica claro quando em O Liberalismo Político, ao explicitar seu argumento de que a concepção política é uma concepção moral, afirma que com isso quer dizer "que o conteúdo é determinado por certos ideais, princípios e critérios; e que essas normas articulam certos valores, nesse caso, valores politicos" (RAWLS, 2000, p. 53).

A propósito da abrangência entre os diferentes contextos normativos de justiça, vale referir Forst. Ao tratar da obediência do Direito, ele mostra como o cidadão, por outro lado, deve assumir a responsabilidade pela sua desobediência. É perfeitamente possivel o apelo a "razões éticas, politicas e morais", para "justificar a violação das obrigações jurídicas" (FORST, 2010, p. 315). A obediência às normas jurídicas não significa um abandono das convicções éticas por parte dos cidadãos. Esse tipo de "resistência", no entanto, deve ser distinguido, segundo o autor, da "resistência politicamente fundamentada" e da resistência ao direito "motivada moralmente". Somente as duas últimas podem ser caracterizadas como desobediência civil. Forst, portanto, situa a objeção de consciência e a desobediência civil nos quatro contextos da justiça: o ético, o jurídico, o político e o moral. Como são quatro contextos normativos diferentes, cabem distintas motivações para o exercicio da resistência às normas jurídicas ambiguas ou injustas.

Como já referido, a principal divergência entre os autores em análise encontra-se nas razões morais, ou seja, na objeção de consciência, como fundamento para a desobediência civil. Na obra Justiça de Toga, Dworkin critica a fundamentação política dos princípios de justiça e a postura exageradamente cautelosa de Rawls em casos de objeção de consciência. Como pano de fundo para sua crítica, Dworkin cita o caso Glucksberg v. Washington, ${ }^{9}$ no qual a discussão central residia na existência ou não de um direito à morte. Ocorre que, no referido caso, diversos juristas e filósofos, entre eles Dworkin e Rawls, assinaram uma petição, conhecida como The philosophers brief. ${ }^{10}$ como amicus curiae defendendo a possibilidade de decisão pessoal do paciente nos casos de suicídio assistido.

A decisão da Suprema Corte, entretanto, foi contrária a um possivel direito à morte, divergindo da opinião dos autores da petição. Dworkin, em todos os escritos que possui no que concerne à discussão quanto a um possivel direito à morte, ${ }^{11}$ reitera a existência de um direito fundamental de decidir o modo de morrer. Rawls, por sua vez, quando questionado sobre a petição dos filósofos (RAWLS; FREEMAN, 1999, p. 618), entende que a decisão da Corte, mesmo que contrária ao seu entendimento, guardava um bom argumento, qual seja: o argumento da cautela.

Nesse ponto, Dworkin, buscando interpretar a própria teoria de Rawls, mormente à concepção de justiça como equidade, entende que o pedido do paciente deveria prevalecer, pois trata-se de uma liberdade básica, vinculada ao primeiro princípio de justiça da teoria ralwsiana. Segundo Dworkin

\begin{abstract}
[...] trata-se de um argumento rawlsiano poderoso e objetivo - e até mesmo decisivo contra o argumento da cautela. Nesses casos litigiosos, um demandante de um grupo de demandantes alega que alguma lei ou prática nega suas liberdades básicas e, desse modo, viola o primeiro princípio da justiça ao qual, na justiça como equidade, se dá prioridade sobre qualquer coisa, ai provavelmente incluidas a paz e a tranquilidade (2019, p. 364).
\end{abstract}

Interessante notar que Dworkin busca interpretações liberais e de prevalência de uma moral subjetiva em detrimento de uma moral objetiva não só em Rawls, mas também em Kant, quando em diversas oportunidades vincula a dignidade

\footnotetext{
8 Forst, ao referir-se à concepção de justiça de Rawls como devendo que ser interpretada como política e não como doutrina "moral abrangente", mostra que "o sentido do termo 'moral', do qual o autor americano se afasta, é no sentido 'ético' de uma concepção que está fundamentada em valores últimos e que se refere à vida boa" (2010, p. 57). Dessa forma, a concepção política é também moral, mas não ética. 9 Sobre a discussão quanto a um possivel direito ao auxilio ao suicidio com referências aos casos citados, ver DWORKIN, 2019, p. 647.

10 Disponivel na integra em: http://www.nybooks.com/articles/1997/03/27/assisted-suicide-the-philosophers-brief/. Acesso em: 20 abr. 2020.

${ }_{11}$ Com destaque para a obra Domínio da Vida e para a obra Direito da Liberdade.
} 
ao exercício da autonomia, promovendo a mais ampla proteção da liberdade negativa. ${ }^{12}$

A discordância fica clara neste ponto. A não inclusão de questões de consciência como fundamento da desobediência civil parece promover, no entendimento de Dworkin, injustiças com determinados grupos. Porém, esse mesmo autor faz justa reverência à grandiosidade da teoria de Rawls, em que pese as inúmeras críticas, razoáveis ou não, que ela possa sofrer. No fim do mesmo capítulo em que critica a aparente mudança de postura de Rawls frente ao direito ao suicídio assistido, e busca reinterpretá-lo, Dworkin esclarece: "a obra dos ícones filosóficos é rica o bastante para permitir a apropriação por meio da interpretação. Cada um de nós tem seu Immanuel Kant, e, a partir de agora, cada um de nós lutará pela bênção de John Rawls" (2019, p. 369).

Não é de espantar, portanto, que mesmo Rawls tendo excluído a objeção de consciência da fundamentação da desobediência civil, que outros autores, como Dworkin, se utilizem da própria teoria rawlsiana para justificar as ações dos dissidentes com fundamentos estritamente morais. O presente ensaio, contudo, não vislumbrou a referida reinterpretação e reitera o entendimento, em Rawls, da necessidade de um procedimento publicamente aceito, vinculado a principios universais de justiça e dentro de regras constitucionalmente asseguradas. Ao passo que entende, em Dworkin, uma aproximação com o conceito tradicional de desobediência civil, no qual a objeção de consciência é, também, fundamento válido para atos contrários a regras injustas ou de validade duvidosa. Certo é, seja qual for a abrangência da desobediência civil, que tal se presta ao melhor funcionamento das sociedades democráticas, de modo que é parte integrante de uma concepção de Estado justo.

\section{Considerações Finais}

Em Rawls fica patente que a concepção mais restrita de desobediência civil tem em vista a viabilidade de um acordo político e sua justifica- ção pública. Razões de consciência, via de regra, não atendem a esses quesitos. Doutrinas éticas abrangentes, sejam filosóficas, religiosas ou de outra ordem, não têm a preocupação de uma justificação pública. Por essa razão Dworkin, ao admitir razões de consciência como justificação da desobediência, amplia por demais seu alcance e deve pagar um preço muito alto para atingir algum tipo de acordo, ainda que de minorias. Como basear a desobediência em valores não politicos? Que tipo de relevância tais valores terão para a justificação pública de principios? É verdade que Rawls está pensando apenas em leis injustas, mas existem também outras instituições cuja validade pode ser questionada.

Ao pressupor uma "sociedade quase justa", com a vigência de um regime constitucional e de uma "concepção publicamente reconhecida", uma concepção de justiça pode parecer pouco realista (RAWLS, 1997, p. 428). No entanto, o autor reconhece a possibilidade de que ocorram diferenças bastante acentuadas nas concepções de justiça entre os cidadãos. Isso não é um problema e faz parte da democracia. O importante é que essas concepções "conduzam a julgamentos políticos semelhantes" (RAWLS, 1997, p. 429). Em todo o caso, em não havendo concordância sobre questões políticas fundamentais, a desobediência civil não se justifica. Aliás, nenhum Estado seria governável. Isso nos faz lembrar Rousseau que em seu Do Contrato Social escreve: "se não houvesse um ponto em que todos os interesses concordassem, nenhuma sociedade poderia existir". E continua: é com "base nesse interesse comum que a sociedade dever der governada" (ROUSSEAU, 1978, p. 43).

O importante é que na condição de cidadãos, quando exercemos o direito de voto, não assinamos um cheque em branco para os nossos legisladores. Não os autorizamos a priori a legislar sobre o que bem entendem. Queremos que atuem em nome da justiça, da dignidade humana e da preservação dos direitos fundamentais. Se isso não ocorrer, o direito de não obedecer deve ser um recurso possivel. Isso faz parte do

12 Ver a discussão quanto ao conceito de dignidade em Domínio da Vida 
exercicio pleno da cidadania e traz estabilidade à democracia. Exercida dentro dos limites da constitucionalidade, a desobediência civil reforça a saúde das instituições justas.

É preciso lembrar que as decisões dos poderes constituidos, principalmente o judiciário, não estão imunes às influências políticas de toda ordem, o que pode levar à revisão de interpretações constitucionais. Se, portanto, uma interpretação da Suprema Corte tiver a pretensão de ter respeitabilidade, deve de alguma forma persuadir a maioria dos cidadãos. A restrição a uma concepção política de justiça torna mais realista a ideia da sociedade bem ordenada e viabiliza um acordo entre as partes envolvidas, ou pelo menos tem maiores chances de consegui-lo. Não se pode falar em desobediência civil sem a pressuposição de um acordo em torno de principios políticos e publicamente aceitos e justificáveis.

Se, portanto, a concepção política de justiça é parte da moral (Rawls) pode-se afirmar com segurança que ela se justifica por razões morais, embora não por razões de consciência (razões éticas). Dworkin amplia a posição de Rawls sustentando, sim, que razões de consciência podem colocar em dúvida a validade de uma lei e, assim, serem usadas para justificar a sua desobediência. O que conta a favor de Rawls é a maior objetividade da justificação da desobediência civil. Somente principios políticos e públicos podem ser arrolados. A dificuldade em Dworkin está no caráter subjetivo das razões de consciência como possivel fonte de resistência. Valores religiosos, por exemplo, poderiam ser motivadores da dubiedade de certas leis. Isso comporta uma enorme dificuldade para um acordo político.

A prevalência de concepções objetivas ou subjetivas de valores morais para a fundamentação da desobediência civil é temática de extrema complexidade. O objetivo do presente estudo não era desvelar a concepção ideal da desobediência civil, mas sim, acrescentar ao debate, promovendo um possivel diálogo entre as teorias apresentadas. Como bem referido por Dworkin, "a obra dos ícones filosóficos é rica o bastante para permitir a apropriação por meio da interpretação"
(2019, p. 369), de modo que novas conclusões quanto ao alcance das teorias, bem como quanto aos limites que elas impõem a valores subjetivos e a valores objetivos da sociedade estarão constantemente a surgir.

\section{Referências}

ALEXY, R. Teoria dos Direitos Fundamentais. São Paulo: Malheiros, 2015.

DWORKIN, R. Levando os Direitos à Sério. São Paulo Martins Fontes, 2002.

DWORKIN, R. A Justiça de Toga. São Paulo: Martins Fontes, 2019.

DWORKIN, R. Domínio da Vida: aborto, eutanásia e liberdades individuais. São Paulo: Martins Fontes, 2009

DWORKIN, R. A Virtude Soberana: a teoria e a prática da igualdade. São Paulo: Martins Fontes, 2009.

ECEIZABARRENA, Juan Ignacio. La Desobediencia Civil em el Estado Constitucional Democrático. Barcelona: Marcial Pons, 1999

FORST, R. Contextos da Justiça. São Paulo: Boitempo, 2010.

PERELMAN, C. Ética e Direito. São Paulo: Martins Fontes, 2005.

RAWLS, J. O Liberalismo Politico. São Paulo: Martins Fontes, 2016.

RAWLS, J. Uma Teoria da Justiça. São Paulo: Martins Fontes, 1997.

RAWLS, J. Colledted Papers. Cambridge, Massachusetts: Harvard University Press, 1999.

ROUSSEAU, J. J. Do Contrato Social. São Paulo: Abril Cultural, 1978. (Coleção Os Pensadores).

VIANA, Marcio Túlio. Direito de Resistência. São Paulo: Editora LTr, 1996.

\section{Andrei Ferreira de Araújo Lima}

Mestre em Direito pela Pontifícia Universidade Católica do Rio Grande do Sul (PUCRS), em Porto Alegre, RS Brasil; doutorando em Filosofia pela Pontificia Universidade Católica do Rio Grande do Sul (PUCRS), em Porto Alegre, RS, Brasil.

\section{Thadeu Weber}

Doutor em Filosofia pela Universidade Federal do Rio Grande do Sul (UFRGS), em Porto Alegre, RS, Brasil; professor nos Programas de Pós-Graduação em Filosofia e em Direito da Pontifícia Universidade Católica do Rio Grande do Sul (PUCRS), em Porto Alegre, RS, Brasil. 


\section{Endereço para correspondência}

Andrei Ferreira de Araújo Lima

Rua Dom Pedro II, 817

Higienópolis, 90550-142

Porto Alegre, RS, Brasil

Thadeu Weber

Pontificia Universidade Católica do Rio Grande do Sul

Av. Ipiranga, 6681, Prédio $11,10^{\circ}$ andar

Partenon, 97010082

Porto Alegre, RS, Brasil 